\title{
Janibacter brevis sp. nov., a new trichloroethylene-degrading bacterium isolated from polluted environments
}

\author{
Yuko Imamura, ${ }^{1}$ Michio Ikeda, ${ }^{1}$ Shin-ichiro Yoshida ${ }^{2}$ \\ and Hiroshi Kuraishi
}

\footnotetext{
1 Environmental Engineering Laboratory, Research and Development Center, Toshiba Corporation, 1 Komukai, Toshiba-cho, Saiwai-Ku, Kawasaki, 210-8582, Japan

2 Japan Food Research Laboratories, Tama Laboratory, 6-11-10, Nagayama, Tama, Tokyo, 206-0025, Japan
}

\begin{abstract}
Author for correspondence: Yuko Imamura. Tel: +81 44549 2167. Fax: +81 445201307. e-mail: yuko.imamura@toshiba.co.jp

Two strains that were strongly able to degrade trichloroethylene were isolated from contaminated environmental samples. The isolates are non-motile, aerobic, non-spore-forming, Gram-positive coccoid to short rods with cell-wall peptidoglycan containing meso-diaminopimelic acid. The major type of menaquinone is $\mathrm{MK}-8\left(\mathrm{H}_{4}\right)$. The polar lipids were diphosphatidylglycerol, phosphatidylglycerol and phosphatidylinositol. Mycolic acids were absent. The G + C content of the DNA was 72 mol\%. Furthermore, comparison of 16S rDNA sequences shows that the isolates clearly belong to the genus Janibacter. The isolates differ from Janibacter limosus at the species level, as shown by the value for DNA-DNA hybridization. It is therefore proposed that the strains be assigned to the genus Janibacter as Janibacter brevis sp. nov.
\end{abstract}

Keywords: Janibacter brevis sp. nov., genus Janibacter, trichloroethylene-degrading bacterium, rRNA sequence

\section{INTRODUCTION}

Large amounts of halogenated aliphatic compounds such as trichloroethylene (TCE) and tetrachloroethylene have been used as solvents for dry cleaning, washing of metal surfaces and other chemical industrial processes. Emission of the compounds into the environment causes contamination of groundwater, soil and sediments. This pollution poses serious health problems because of the toxic and carcinogenic properties of the compounds (Davidson et al., 1982; Infante $\&$ Tsongas, 1982). Gram-positive and -negative bacteria that degrade chlorinated aliphatic hydrocarbons aerobically have been found by many investigators. Among the Gram-positive bacteria identified are Arthrobacter sp. (Scholtz et al., 1987), Corynebacterium sp. m15-3 (Yokota et al., 1987), Rhodococcus erythropolis Y2 (Sallis et al., 1990), Mycobacterium aurum L1 (Hartmans \& De Bont, 1992), Rhodococcus rhodochrous and other Rhodococcus strains (Malachowsky et al., 1994). Recently, cometabolic degradation of TCE was evaluated in reactors with distinct phenol-feeding patterns (Shin

Abbreviation: TCE, trichloroethylene.

The DDBJ accession numbers for the 16S rRNA gene sequences of strains $10 N^{\top}$ and $16 \mathrm{~N}$ are $\mathrm{AB} 016438$ and $\mathrm{AB} 016439$. et al., 1996). However, the active microbes were not specified in systems characterized by higher concentrations of TCE-degrading organisms and higher rates of TCE transformation.

We isolated two strains that were strongly able to degrade TCE from contaminated environmental samples. The isolates belonged to the genus Janibacter established by Martin et al. (1997). We describe here the phenotypic and phylogenetic characterization of Janibacter-like organisms. On the basis of the taxonomic results shown below, a new species, Janibacter brevis sp. nov., is described.

\section{METHODS}

Isolation and cultivation. Inorganic salt agar medium (Kimbara et al., 1988) was placed at the bottom of a tightly closed plastic container (about $20 \mathrm{ml}$ ) and a groundwater sample was inoculated on the surface of the medium with $0.5 \%$ agar and $0 \cdot 1 \mathrm{M}$ phosphate buffer. The aerial part of the vessels contained 8000 p.p.m. TCE vapour and the vessels were incubated at $25^{\circ} \mathrm{C}$ until bacterial colonies appeared on the medium. Among the strains obtained from various colonies, two strains, $10 \mathrm{~N}^{\mathrm{T}}$ and $16 \mathrm{~N}$, which showed higher levels of TCE degradation, were selected as representatives. The isolates were stored on plates of LB agar [10 g tryptone (Difco), $5 \mathrm{~g}$ yeast extract (Difco), $10 \mathrm{~g} \mathrm{NaCl}$ and $15 \mathrm{~g}$ agar (Difco) $\mathrm{1}^{-1}$ ] and in frozen LB liquid medium with $15 \%(\mathrm{v} / \mathrm{v})$ glycerol. 
Morphological and cultural characteristics. For morphological and cultural observation, bouillon agar (NA) containing $10 \mathrm{~g}$ meat extract (Kyokuto, Tokyo, Japan), $5 \mathrm{~g}$ bacteriological peptone (Oxoid), $5 \mathrm{~g} \mathrm{NaCl}$ and $15 \mathrm{~g}$ agar (Difco) $1^{-1}$ and LB medium with or without agar (Difco) were used at $30^{\circ} \mathrm{C}$. Gram staining was performed with a FAVOR.EG SET.EF kit (Nissui Pharmaceutical Co.). Cells grown on NA were used for acid-fast and motility tests.

Physiological characteristics. Acid production from carbohydrates was determined with a phenol red broth medium (Difco). Utilization of carbon sources was studied with the medium described by Stanier et al. (1966) with a small amount of thiamine. Decomposition of adenine, casein, hypoxanthine, tyrosine and xanthine was examined by the method recommended by Gordon et al. (1974).

Quinone, lipid, fatty acid, mycolic acid and cell wall analyses. These analyses were carried out by using cells grown in trypticase soy broth (BBL) with $0.5 \%$ yeast extract (Difco) (TSY medium). Quinones were extracted twice from lyophilized cells with chloroform-methanol $(2: 1, \mathrm{v} / \mathrm{v})$ for 20 min, partially purified by TLC with benzene as the solvent and analysed by reverse-phase HPLC (Tamaoka et al., 1983), with a model 510 (Waters) and a Lambda-Max model 481 (Waters) and a Wakosil-II5C18 HG column $(4.6 \times 150 \mathrm{~mm}$; Wako Pure Chemical Industries), with methanol/2-propanol $(2: 1, \mathrm{v} / \mathrm{v})$ as the eluting solvent. Polar lipids were extracted and identified by the method of Minnikin et al. (1984). Fatty acids, mycolic acids and cell wall were analysed by the method described by Komagata \& Suzuki (1987). The glycolyl test was performed by the method of Uchida \& Aida (1984).

DNA base composition and DNA-DNA hybridization. DNA was isolated and its $\mathrm{G}+\mathrm{C}$ content determined by HPLC as described by Tamaoka \& Komagata (1984). For DNADNA hybridization, levels of DNA relatedness were measured by the method of Takahashi et al. (1993) using photobiotin and microimmunoplates.

Amplification and sequencing of 16S rRNA genes. Cells were grown in LB broth, harvested by centrifugation in the lateexponential phase of growth, washed with sterile $1 \%(\mathrm{w} / \mathrm{v})$ saline, resuspended in $100 \mu \mathrm{l}$ sterile distilled water and stored at $-20{ }^{\circ} \mathrm{C}$ until used. The preparation of crude lysates for amplification by PCR, the sequence of oligonucleotide primers, their target sites and electrophoretic separation conditions have been described previously (Hiraishi, 1992; Hiraishi et al., 1994; Katayama et al., 1995).

Phylogenetic analysis. Pairs of sequences were aligned with the GENE WORKS software. Multiple alignment of sequences, calculation of nucleotide substitution rates $\left(K_{\text {nuc }}\right)$ (Kimura, 1980) and construction of neighbour-joining phylogenetic trees (Saitou \& Nei, 1987) were performed with the CLUSTAL w program (Thompson et al., 1994). Alignment positions that included gaps or unidentified bases were eliminated from the calculations. After the alignment process, sequences of $16 \mathrm{~S}$ rDNA were adjusted manually. Confidence intervals of the branch points were determined by the bootstrap technique (Felsenstein, 1985) with 1000 bootstrapped trials.

Nucleotide sequence accession numbers. The strain designations and accession numbers of reference 16S rRNA sequences are as follows: Intrasporangium calvum ATCC 23552 ${ }^{\mathrm{T}}$, D85486; Janibacter limosus DSM 11140 ${ }^{\mathrm{T}}$, Y08539; J. limosus DSM 11141, Y08540; Sanguibacter inulinus NCFB 3024 ${ }^{\mathrm{T}}$, X79451; Sanguibacter keddieii NCFB 3025 ,
X79450; Sanguibacter suarezii NCFB 3023 ${ }^{\mathrm{T}}$, X79452; Terrabacter tumescens IAM 12345 ${ }^{\mathrm{T}}$, X83812; and Terracoccus luteus DSM 44267 ${ }^{\mathrm{T}}$, Y11928.

\section{RESULTS AND DISCUSSION}

\section{Morphological and cultural characteristics}

Colonies of both strains $10 \mathrm{~N}^{\mathrm{T}}$ and $16 \mathrm{~N}$ are white, opaque and convex with a glistening surface and entire margins on NA and LB media. Cells are Grampositive, non-acid-fast and non-motile, occur singly, in pairs or occasionally in v-shaped clumps at the early stage of growth. Cells are short rods in young culture, $0.9-1.0 \mu \mathrm{m}$ in diameter and $1.5-1.8 \mu \mathrm{m}$ long, and
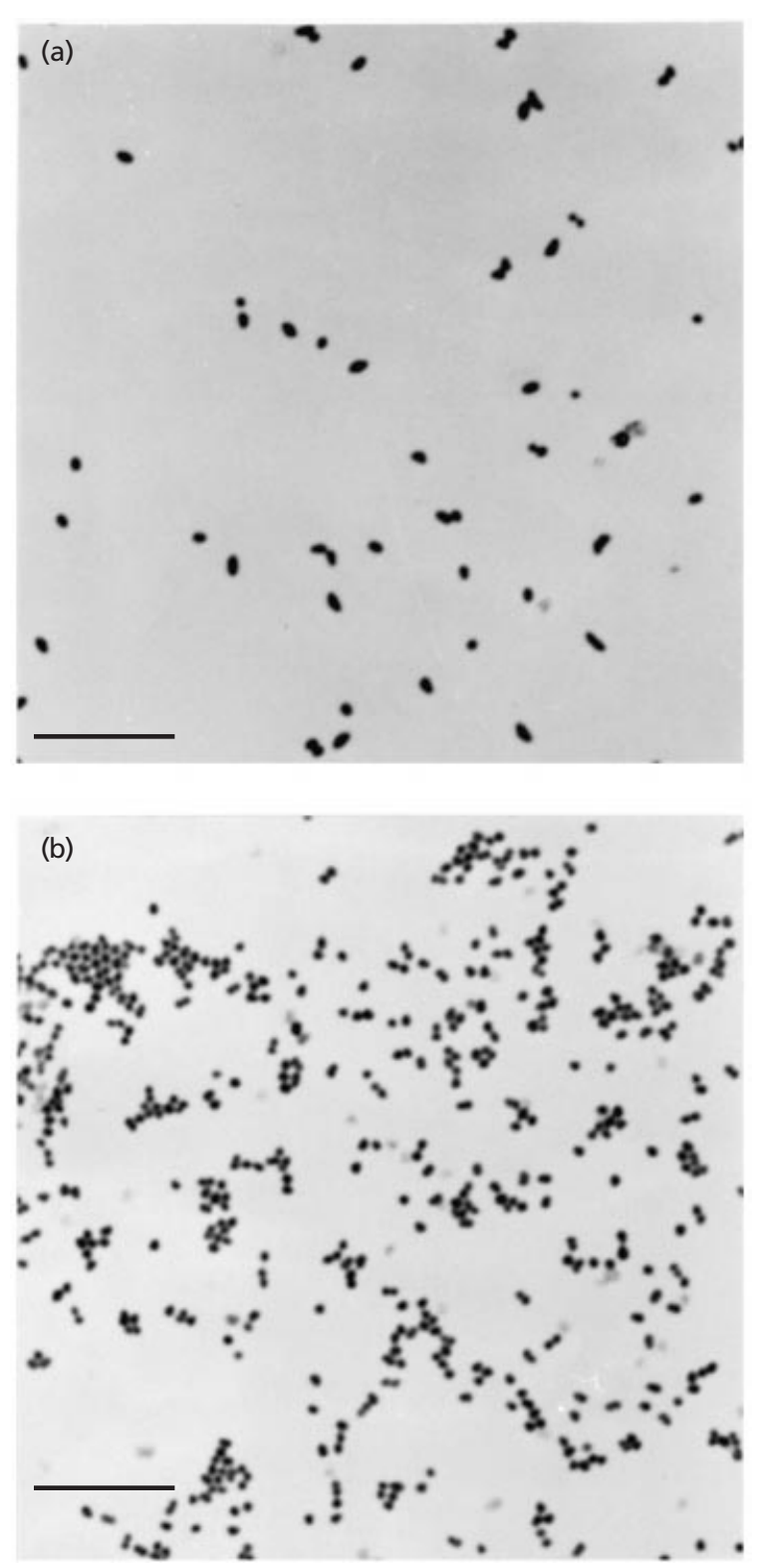

Fig. 1. Micrographs of cells of strain $10 N^{\top}$ grown on NA medium at $30^{\circ} \mathrm{C}$ for $6 \mathrm{~h}$ (a) and $24 \mathrm{~h}$ (b). Bars, $10 \mu \mathrm{m}$. 
Table 1. Comparison of morphological and biochemical characteristics of isolates $10 \mathrm{~N}^{\top}$ and $16 \mathrm{~N}$ with J. limosus strains

Data for J. limosus were taken from Martin et al. (1997) unless stated otherwise. Characteristics are scored as positive (+) or negative (-). All taxa were positive for the following characters: Gram reaction, obligately aerobic growth, utilization of citrate, decomposition of casein and tyrosine, nitrate reduction, catalase reaction, growth in the presence of $7 \% \mathrm{NaCl}$. All taxa were negative for the following characters: motility, spore formation, acid production from L-arabinose, D-fructose, D-glucose, lactose, maltose, sucrose, trehalose, D-raffinose, starch and glycerol, utilization of cis-aconitate, trans-aconitate, benzoate, succinate and L-tartarate, decomposition of adenine, hypoxanthine and xanthine, production of indole, Voges-Proskauer test, methyl red test, oxidase test, growth in the presence of $10 \% \mathrm{NaCl}$.

\begin{tabular}{|c|c|c|c|c|}
\hline Characteristic & $10 N^{T}$ & $16 N$ & $\begin{array}{c}\text { J. limosus } \\
\text { DSM 11140 }\end{array}$ & $\begin{array}{c}\text { J. limosus } \\
\text { DSM } 11141\end{array}$ \\
\hline Colour of colonies & White & White & White & Yellow \\
\hline Morphology & Short rod to coccoid & Short rod to coccoid & Coccoid, rod & Coccoid \\
\hline \multicolumn{5}{|l|}{ Utilization of: } \\
\hline D-Mannose & - & - & + & + \\
\hline Lactose & + & + & $-\dagger$ & $-\dagger$ \\
\hline Acetate & + & + & + & - \\
\hline Formate & - & - & + & + \\
\hline Hippurate & + & + & - & - \\
\hline Malate & - & - & + & + \\
\hline Requirement of thiamine for growth & + & + & - & - \\
\hline Production of $\mathrm{H}_{2} \mathrm{~S}$ & - & - & + & + \\
\hline \multicolumn{5}{|l|}{ Growth in the presence of:* } \\
\hline $8 \% \mathrm{NaCl}$ & + & + & + & - \\
\hline $9 \% \mathrm{NaCl}$ & - & + & - & - \\
\hline
\end{tabular}

* Cultured for 2 weeks; all data taken from this study.

$\dagger$ Determined in this study.

coccoid cells in the stationary phase of growth that are $1 \cdot 0-1 \cdot 2 \mu \mathrm{m}$ in diameter and $1 \cdot 2-1 \cdot 3 \mu \mathrm{m}$ long (Fig. 1). Spore formation and a marked rod-coccus cycle were not observed. Both strains are obligately aerobic. They grow within a week at 4 and $39^{\circ} \mathrm{C}$ and optimal growth was observed at $25-28^{\circ} \mathrm{C}$.

\section{Physiological characteristics}

A comparison of physiological characteristics of $10 \mathrm{~N}^{\mathrm{T}}$ and $16 \mathrm{~N}$ with two strains of $J$. limosus is shown in Table 1. The characteristics of both strains are similar to those of $J$. limosus, but thiamine is required for growth of the isolates. Acid was not produced from any of the substrates tested (L-arabinose, D-fructose, D-glucose, lactose, maltose, sucrose, trehalose, Draffinose, starch and glycerol). Lactose and hippurate were utilized only by strains $10 \mathrm{~N}^{\mathrm{T}}$ and $16 \mathrm{~N}$. On the other hand, D-mannose, formate and malate were utilized only by $J$. limosus.

\section{Chemotaxonomic characteristics}

Cell wall murein analysis of the two isolates revealed that meso-diaminopimelic acid was the dibasic amino acid. The acyl type was acetyl. The organisms did not contain arabinose or galactose, but ribose and glucose were present in whole-cell hydrolysates. Strains $10 \mathrm{~N}^{\mathrm{T}}$ and $16 \mathrm{~N}$ resemble each other in their cellular fatty acid profiles (Table 2). They are characterized by branched fatty acids such as $\mathrm{i}-\mathrm{C}_{15: 0}, \mathrm{i}-\mathrm{C}_{16: 0}, \mathrm{i}-\mathrm{C}_{17: 0}, \mathrm{i}-\mathrm{C}_{17: 1}$, ai$\mathrm{C}_{17: 0}$ and $\mathrm{C}_{18: 1}\left(\Delta^{11}\right)$ as well as minor amounts of straight chain unsaturated $\left(\mathrm{C}_{16: 0}, \mathrm{C}_{17: 0}\right.$ and $\left.\mathrm{C}_{18: 0}\right)$ and saturated $\left(\mathrm{C}_{17: 1}\right)$ acids. These profiles differ from those of $J$. limosus, which consist of $\mathrm{C}_{17: 1}, \mathrm{C}_{17: 0}$ and $\mathrm{i}-\mathrm{C}_{16: 0}$ as major components as well as minor amounts of straight chain saturated and unsaturated fatty acids. The isoprenoid quinone was represented by $\mathrm{MK}-8\left(\mathrm{H}_{4}\right)$ as the major component. Mycolic acids were absent.

\section{DNA base composition}

The DNA base composition of strains $10 \mathrm{~N}^{\mathrm{T}}$ and $16 \mathrm{~N}$ was $72 \mathrm{~mol} \% \mathrm{G}+\mathrm{C}$.

\section{DNA-DNA relatedness}

The level of DNA-DNA relatedness between strains $10 \mathrm{~N}^{\mathrm{T}}$ and $16 \mathrm{~N}$ was $97 \%$. The DNA-DNA relatedness to other species was therefore determined using strain $10 \mathrm{~N}^{\mathrm{T}}$. DNA of strain $10 \mathrm{~N}^{\mathrm{T}}$ exhibited homology values of $51-47 \%$ to DNA from two strains of J. limosus, DSM $11140^{\mathrm{T}}$ and DSM 11141. As shown in Table 3, strains $10 \mathrm{~N}^{\mathrm{T}}$ and $16 \mathrm{~N}$ both belonged to different species from $J$. limosus. 
Table 2. Cellular fatty acid profiles for isolates $10 \mathrm{~N}^{\top}$ and $16 \mathrm{~N}$ and $J$. limosus strains

\begin{tabular}{|c|c|c|c|c|}
\hline $\begin{array}{l}\text { Fatty } \\
\text { acid }\end{array}$ & $10 N^{T}$ & $16 \mathrm{~N}$ & $\begin{array}{c}\text { J. limosus } \\
\text { DSM 11140 }\end{array}$ & $\begin{array}{c}\text { J. limosus } \\
\text { DSM } 11141\end{array}$ \\
\hline $\mathrm{i}-\mathrm{C}_{14: 0}$ & - & - & $0 \cdot 5$ & $0 \cdot 7$ \\
\hline $\mathrm{C}_{14: 0}$ & - & - & $0 \cdot 4$ & $0 \cdot 2$ \\
\hline $\mathrm{i}-\mathrm{C}_{15: 0}$ & $13 \cdot 8$ & $12 \cdot 2$ & $1 \cdot 7$ & $0 \cdot 7$ \\
\hline ai- $C_{15: 0}$ & $1 \cdot 2$ & $1 \cdot 1$ & $0 \cdot 3$ & $0 \cdot 1$ \\
\hline $\mathrm{C}_{15: 0}$ & $0 \cdot 3$ & $0 \cdot 3$ & $3 \cdot 8$ & 0.9 \\
\hline$C_{15: 1}^{10.0}$ & - & - & $0 \cdot 3$ & $0 \cdot 3$ \\
\hline $\mathrm{i}-\mathrm{C}_{16: 0}$ & $21 \cdot 4$ & $22 \cdot 6$ & $17 \cdot 5$ & $40 \cdot 8$ \\
\hline $\mathrm{i}-\mathrm{C}_{16: 1}$ & - & - & - & $0 \cdot 3$ \\
\hline ai- $C_{16: 0}$ & $0 \cdot 2$ & $0 \cdot 2$ & - & - \\
\hline $\mathrm{C}_{16: 0}$ & $2 \cdot 9$ & $3 \cdot 0$ & $3 \cdot 9$ & $1 \cdot 3$ \\
\hline $\mathrm{C}_{16: 1}$ & - & - & $2 \cdot 4$ & $2 \cdot 6$ \\
\hline $\mathrm{i}-\mathrm{C}_{17: 0}$ & $16 \cdot 1$ & $16 \cdot 4$ & $1 \cdot 3$ & $1 \cdot 0$ \\
\hline $\mathrm{i}-\mathrm{C}_{17: 1}$ & $10 \cdot 2$ & $10 \cdot 1$ & - & $0 \cdot 2$ \\
\hline ai- $C_{17: 0}$ & $10 \cdot 1$ & $10 \cdot 0$ & - & - \\
\hline ai- $C_{17: 1}$ & - & - & $0 \cdot 2$ & $0 \cdot 1$ \\
\hline$C_{17: 0}$ & $2 \cdot 1$ & $2 \cdot 1$ & $20 \cdot 5$ & $5 \cdot 0$ \\
\hline $\mathrm{C}_{17: 1}$ & $2 \cdot 0$ & $2 \cdot 4$ & $29 \cdot 7$ & $27 \cdot 6$ \\
\hline $\mathrm{i}-\mathrm{C}_{18: 0}$ & - & - & $1 \cdot 4$ & $0 \cdot 3$ \\
\hline $\mathrm{i}-\mathrm{C}_{18: 1}$ & - & - & $0 \cdot 7$ & $2 \cdot 9$ \\
\hline$C_{18: 0}$ & $2 \cdot 5$ & $3 \cdot 5$ & $2 \cdot 4$ & $0 \cdot 7$ \\
\hline $\mathrm{C}_{18: 1}\left(\Delta^{9}\right)$ & $1 \cdot 1$ & $1 \cdot 1$ & - & - \\
\hline $\mathrm{C}_{18: 1}\left(\Delta^{11}\right)$ & $16 \cdot 1$ & $15 \cdot 0$ & $8 \cdot 1$ & $8 \cdot 5$ \\
\hline
\end{tabular}

\section{$16 S$ rDNA phylogenetic analysis}

Two almost complete 16S rRNA sequences were obtained from isolates $10 \mathrm{~N}^{\mathrm{T}}$ (1487 nucleotides) and $16 \mathrm{~N}$ (1470 nucleotides). A phylogenetic tree is depicted in Fig. 2. A total of 1371 nucleotides present in all strains between positions 22 and 1524 (E. coli numbering) were used for this analysis. The phylogenetic positions of both strains were found to be close to $J$. limosus. The level of $16 \mathrm{~S}$ rDNA sequence similarity between strains $10 \mathrm{~N}^{\mathrm{T}}$ and $16 \mathrm{~N}$ was $98 \%$ when all 1470
Table 3. DNA-DNA hybridization between isolate $10 \mathrm{~N}^{\top}$ and related strains

\begin{tabular}{|lc|}
\hline Strain & $\begin{array}{c}\text { DNA-DNA } \\
\text { hybridization } \\
\text { with 10N }\end{array}$ \\
\hline $10 \mathbf{N}^{\mathrm{T}}$ & \\
J. limosus DSM 11140 & 100 \\
J. limosus DSM 11141 & 51 \\
Terrabacter tumescens IAM 12345 & 47 \\
Sanguibacter keddieii ATCC 51767 & 22 \\
Nocardioides simplex IAM 1660 & 24 \\
Corynebacterium ammoniagenes IAM 1641 & 11 \\
Escherichia coli IAM 12119 & 6 \\
\hline
\end{tabular}

aligned nucleotide positions were compared. The level of $16 \mathrm{~S}$ rDNA sequence similarity to J. limosus ranged from 96 to $98 \%$.

On the bases of morphological and cultural characteristics, physiological characteristics, chemotaxonomic characters and the phylogenetic position of 16S rRNA sequences, the TCE-degrading isolates clearly belong to the genus Janibacter, but differ from J. limosus at the species level, as shown by the value for DNA-DNA hybridization. It is therefore proposed that the strains be assigned to the genus Janibacter as Janibacter brevis sp. nov. An examination of the ability of strains $10 \mathrm{~N}^{\mathrm{T}}$ and $16 \mathrm{~N}$ to degrade TCE will be published elsewhere.

\section{Description of Janibacter brevis sp. nov.}

Janibacter brevis (bre'vis. L. adj. brevis short).

Colonies are white, opaque and convex with a glistening surface and entire margins on good growth media. Cells are Gram-positive and non-motile, occur singly, in pairs or occasionally in $\mathrm{v}$-shaped clumps at the early stage of growth. Cells are short rods in young culture, $0.9-1.0 \mu \mathrm{m}$ in diameter and $1.5-1 \cdot 8 \mu \mathrm{m}$ long, and coccoid cells in the stationary phase of growth,

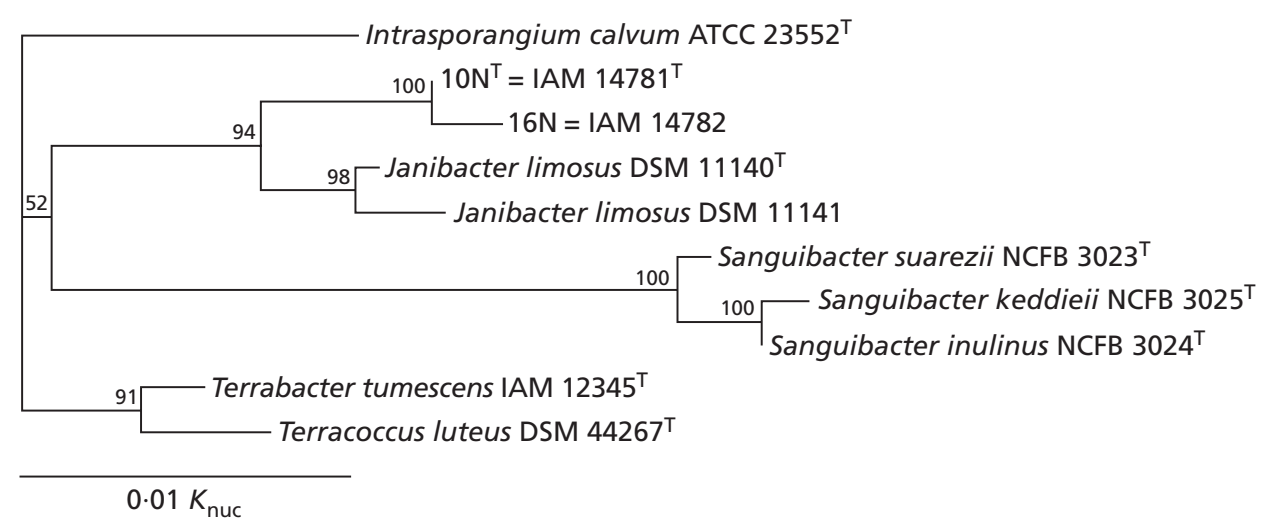

Fig. 2. Phylogenetic tree based on results of a $16 \mathrm{~S}$ rDNA sequence comparison. Bootstrap values over $50 \%$ are shown at branch points. 
$1 \cdot 0-1 \cdot 2 \mu \mathrm{m}$ in diameter and $1 \cdot 2-1 \cdot 3 \mu \mathrm{m}$ long. A marked rod-coccus cycle is not observed. The optimal growth temperature is $25-28{ }^{\circ} \mathrm{C}$. Obligately aerobic. Chemoorganotrophic. Oxidase-negative. Catalase-positive. $\mathrm{H}_{2} \mathrm{~S}$ and indole are not produced. Nitrate is reduced to nitrite. Thiamine is required for growth. Formation of acids from sugars and alcohols is not observed. Cells utilize D-fructose, D-glucose, lactose, maltose, sucrose, trehalose, inositol, acetate, butyrate, citrate, gluconate, hippurate, DL-lactate, pyruvate, valeric acid and various amino acids as sole carbon sources. L-Arabinose, D-xylose, D-mannose, L-sorbose, D-cellobiose, galactose, mannitol, D-sorbitol, methanol, ethanol, propanol, cis-aconitate, trans-aconitate, benzoate, formate, malate, malonate, succinate and L-tartarate are not utilized. meso-Diaminopimelic acid is contained in peptidoglycan. The acyl type is acetyl. In whole-cell hydrolysates, ribose and glucose are present, but arabinose, galactose and mannose are absent. The major menaquinone is $\mathrm{MK}-8\left(\mathrm{H}_{4}\right)$. The major fatty acids are $\mathrm{i}-\mathrm{C}_{15: 0}, \mathrm{i}-\mathrm{C}_{16: 0}, \mathrm{i}-\mathrm{C}_{17: 0}, \mathrm{i}-\mathrm{C}_{17: 1}$ and ai- $\mathrm{C}_{17: 0}$ as the branched acids and $\mathrm{C}_{18: 1}\left(\Delta^{11}\right)$ as the straight chain acid. The polar lipids are diphosphatidylglycerol, phosphatidylglycerol and phosphatidylinositol. Mycolic acids are absent. The DNA base composition is $72 \mathrm{~mol} \% \mathrm{G}+\mathrm{C}$.

The type strain is strain $10 \mathrm{~N}^{\mathrm{T}}$. Strains $10 \mathrm{~N}^{\mathrm{T}}$ and $16 \mathrm{~N}$ have been deposited in the IAM (Institute of Cellular and Molecular Sciences, University of Tokyo) Culture Collection as IAM $14781^{\mathrm{T}}$ and IAM 14782, respectively.

\section{ACKNOWLEDGEMENTS}

We thank Shigenori Ohtani for excellent technical assistance.

\section{REFERENCES}

Davidson, I. W. F., Sumner, D. D. \& Parker, J. C. (1982). Chloroform: a review of its metabolism, teratogenic, mutagenic, and carcinogenic potential. Drug Chem Toxicol 5, 1-87.

Felsenstein, J. (1985). Confidence intervals on phylogenies: an approach using the bootstrap. Evolution 39, 783-791.

Gordon, R. E., Barnett, D. A., Handerhan, J. E. \& Pang, C. H.-N. (1974). Nocardia coeliaca, Nocardia autotrophica, and the nocardin strain. Int J Syst Bacteriol 24, 54-63.

Hartmans, S. \& De Bont, J. A. M. (1992). Aerobic vinyl chloride metabolism in Mycobacterium aurum L1. Appl Environ Microbiol 58, 1220-1226.

Hiraishi, A. (1992). Direct automated sequencing of 16S rDNA amplified by polymerase chain reaction from bacterial cultures without DNA purification. Lett Appl Microbiol 15, 210-213.

Hiraishi, A., Shin, A. Y., Ueda, Y. \& Sugiyama, J. (1994). Automated sequencing of PCR-amplified 16S rDNA on “Hydrolink" gels. J Microbiol Methods 19, 145-154.

Infante, P. F. \& Tsongas, T. A. (1982). Mutagenic and oncogenic effects of chloromethanes, chloroethanes, and halogenated analogues of vinyl chloride. Environ Sci 25, 301-327.

Katayama, Y., Hiraishi, A. \& Kuraishi, H. (1995). Paracoccus thiocyanatus sp. nov., a new species of thiocyanate-utilizing facultative chemolithotroph, and transfer of Thiobacillus ver- sutus to the genus Paracoccus as Paracoccus versutus comb. nov. with emendation of the genus. Microbiology 141, 1469-1477.

Kimbara, K., Hashimoto, T., Fukuda, M., Koana, T., Takagi, M. \& Yano, K. (1988). Isolation and characterization of a mixed culture that degrades polychlorinated biphenyls. Agric Biol Chem 52, 2885-2891.

Kimura, M. (1980). A simple method for estimating evolutionary rates of base substitutions through comparative studies of nucleotide sequences. J Mol Evol 16, 111-120.

Komagata, K. \& Suzuki, K. (1987). Lipid and cell-wall analysis in bacterial systematics. Methods Microbiol 19, 161-207.

Malachowsky, K. J., Phelps, T. J., Teboli, A. B., Minnikin, D. E. \& White, D. C. (1994). Aerobic mineralization of trichloroethylene, vinyl chloride, and aromatic compounds by Rhodococcus species. Appl Environ Microbiol 60, 542-548.

Martin, K., Schumann, P., Rainey, F. A., Schuetze, B. \& Groth, I. (1997). Janibacter limosus gen. nov., sp. nov., a new actinomycete with meso-diaminopimelic acid in the cell wall. Int $J$ Syst Bacteriol 47, 529-534.

Minnikin, D. E., O'Donnell, A. G., Goodfellow, M., Alderson, G., Athalye, M., Schaal, A. \& Parlett, J. H. (1984). An integrated procedure for the extraction of bacterial isoprenoid quinones and polar lipids. J Microbiol Methods 2, 233-241.

Saitou, N. \& Nei, M. (1987). The neighbor-joining method: a new method for reconstructing phylogenetic trees. Mol Biol Evol 4, 406-425.

Sallis, P. J., Armfield, S. J., Bull, A. T. \& Hardman, D. J. (1990). Isolation and characterization of a haloalkane halidohydrolase from Rhodococcus erythropolis Y2. J Gen Microbiol 136, 115-120.

Scholtz, R., Leisinger, T., Suter, F. \& Cook, A. M. (1987). Characterization of 1-chlorohexane halidohydrolase, a dehalogenase of wide substrate range from an Arthrobacter sp, J Bacteriol 169, 5016-5021.

Shin, C.-C., Davey, M. E., Zhou, J., Tiedje, M. \& Criddle, C. S. (1996). Effects of phenol feeding pattern on microbial community structure and cometabolism of trichloroethylene. Appl Environ Microbiol 62, 2953-2960.

Stanier, R. Y., Palleroni, N. J. \& Doudoroff, M. (1966). The aerobic pseudomonads: a taxonomic study. J Gen Microbiol 43, 159-271.

Takahashi, M., Lee, F. L. \& Okada, S. (1993). Quantitative measurement of DNA-DNA hybridization for determination of genetic relatedness among bacterial strains. Bull Isotope Center Tokyo Univ Agric 7, 69-75 (in Japanese).

Tamaoka, J. \& Komagata, K. (1984). Determination of base composition by reversed phase high-performance liquid chromatography. FEMS Microbiol Lett 25, 125-128.

Tamaoka, J., Katayama-Fujimura, Y. \& Kuraishi, H. (1983). Analysis of bacterial menaquinone mixtures by high performance liquid chromatography. J Appl Bacteriol 54, 31-36.

Thompson, J. D., Higgins, D. G. \& Gibson, T. J. (1994). CLUSTAL W: improving the sensitivity of progressive multiple sequence alignment through sequence weighting, position-specific gap penalties and weight matrix choice. Nucleic Acids Res 22, 4673-4680.

Uchida, K. \& Aida, K. (1984). An improved method for the glycolate test for simple identification of the acyl type of bacterial cell walls. J Gen Appl Microbiol 30, 131-134.

Yokota, T., Omori, T. \& Kodama, T. (1987). Purification and properties of haloalkane dehalogenase from Corynebacterium sp. m15-3. J Bacteriol 169, 4049-4054. 